\title{
On competitive potential of organization under conditions of new industrial base formation
}

\author{
TimurAblyazov ${ }^{1}$, and Veronika Asaul ${ }^{1 *}$ \\ ${ }^{1}$ Saint Petersburg State University of Architecture and Civil Engineering, Faculty of economics and \\ management, 190005 2-ya Krasnoarmeiskaya st. 4,Russian Federation
}

\begin{abstract}
The world data volume will increase 10 times by 2025 to equal 163 ZettaByte. More than $95 \%$ of data will be transmitted in real time by the devices incorporated into network, which is the key feature of new industrial base formation [1]. Even today the information technology gap between economies of the developed and developing countries spells not only a reduction of competitiveness of organizations and individual branches of economy, but the loss of national technological sovereignties. This article considers a system of providing competitiveness of an organization, which is connected with the innovative business model of development and is supported by such a component of entrepreneurial business, as the information technology interaction of entities of social and economic relations.
\end{abstract}

A transition to the sixths technological mode, which takes place under conditions of intensification of globalization processes and risks, is connected with formation of "digital economics" with the new scientific knowledge and competencies, information and communications technologies and innovative production as the most important factor of its development.

In spite of the widely used term "digital economics", no universally accepted scientific definition has been elaborated. The article authors have worded the following definition: digital economics is a controlled system of social and economic relations, where the involvement of resources, interaction of subjects and objects as well as acquisition of valuable result are provided in the way of exchanging digital data on the parameters and properties of every system element by means of information and communications technologies.

Mastercard and Fletcher School of Law and Diplomatic Activity [2] have provided Digital Evolution Index 2017 rating. The study reflects a progress in formation of digital economics in different countries as well as a level of global network penetration into social and economic links of billions of people. Nowadays more than a half of the world population uses Internet. The study results show competitiveness and potential of development of digital economics in 60 countries. Digital Evolution Index 2017 rating appraises every state by 170 unique parameters.

They describe 4 basic factors, which determine the rate of digital economics elements incorporation:

*Corresponding author: asaul@inbox.ru 
- offer level (availability of access to Internet and degree of infrastructure development);

- demand of customers for digital technologies;

- institutional environment (state policy, legislation, resources);

- innovative climate (investments into R\&D and digital-startups).

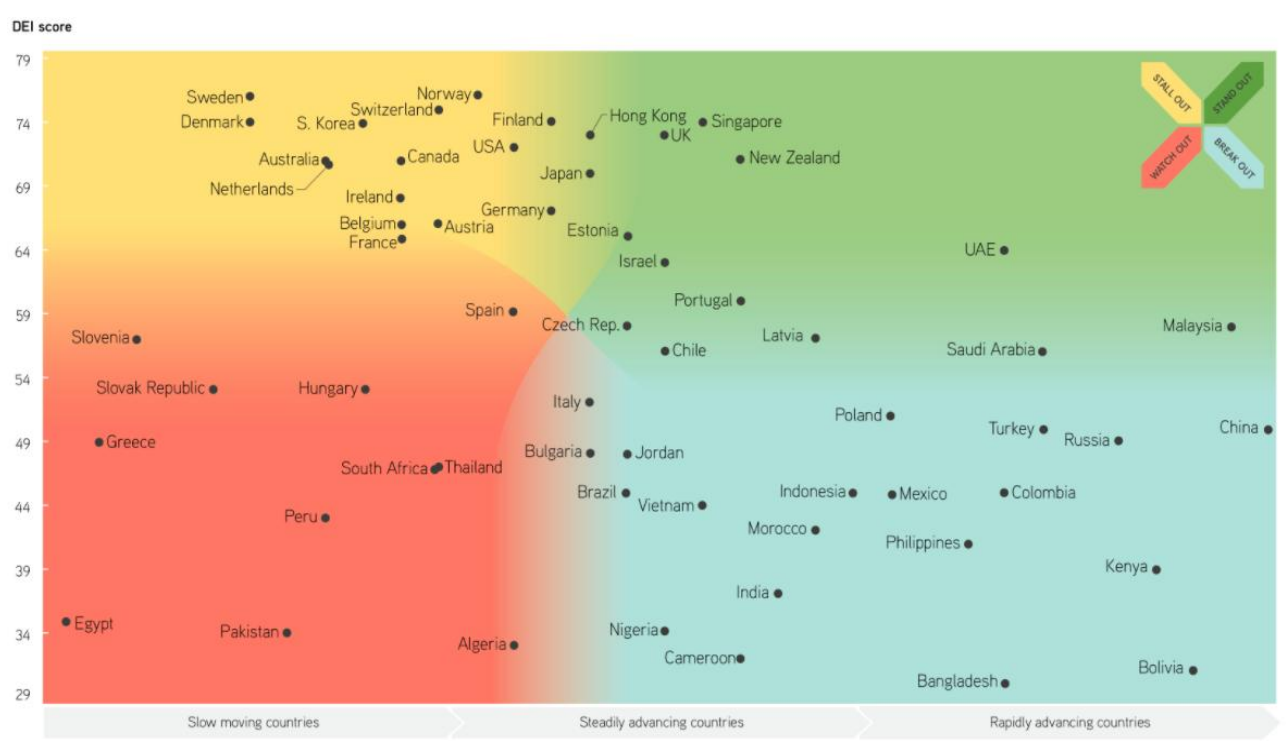

Fig. 1. Assessment of development of digital economics by combination of four factors [2].

Proceeding from the results of this study Singapore, Great Britain, New Zealand, the United Arab Emirates, Estonia, Hong Kong, Japan and Israel have become "digital nobles": these countries get characterized by high level and high rate of development of digital development. Owing to such speed of incorporating innovations at all levels of peoples' lives, business and interaction with state, these progressive markets can serve an example of successful technological progress and milestones for future growth.

Russia belongs to a group of promising countries with rather low level of penetration of elements of digital economics due to undeveloped infrastructure and low quality of institutional environment. In this case significant dynamics and great potential of economic development are observed. In order to use the existing social and economic potential a program "Digital economics of the Russian Federation" has been developed to be approved by the Resolution of the Government No.1632-r dated July 28, 2017. The adoption of this document determines a necessity of developing new methods of entrepreneurial business development, since the classical principles of interaction of entrepreneurial business entities can not provide for necessary speed of information transmission and taking managerial decisions as well as required level of production cost and transaction expenses. 
According to this program the digital economics is represented by three following levels, which influence in the close rapport the life of people and community as a whole:

- markets and branches of economy (sphere of activity), where interaction of particular entities (suppliers and consumers of goods, works and services) takes place;

- platforms and technologies, where the competencies for development of markets and branches of economy (sphere of activity) get formed;

- environment creating conditions for the development of platforms and technologies and efficient interaction of entities of markets and branches of economy (sphere of activity) encompassing regulatory control, informational infrastructure, human resources and informational safety [3].

The formation of new conditions for social and economic interaction entailed a change of forms and methods of organization of business entities as well as labor market. Fig. 2 shows the intensity of everyday use of information and communication technologies (ICT) in work.

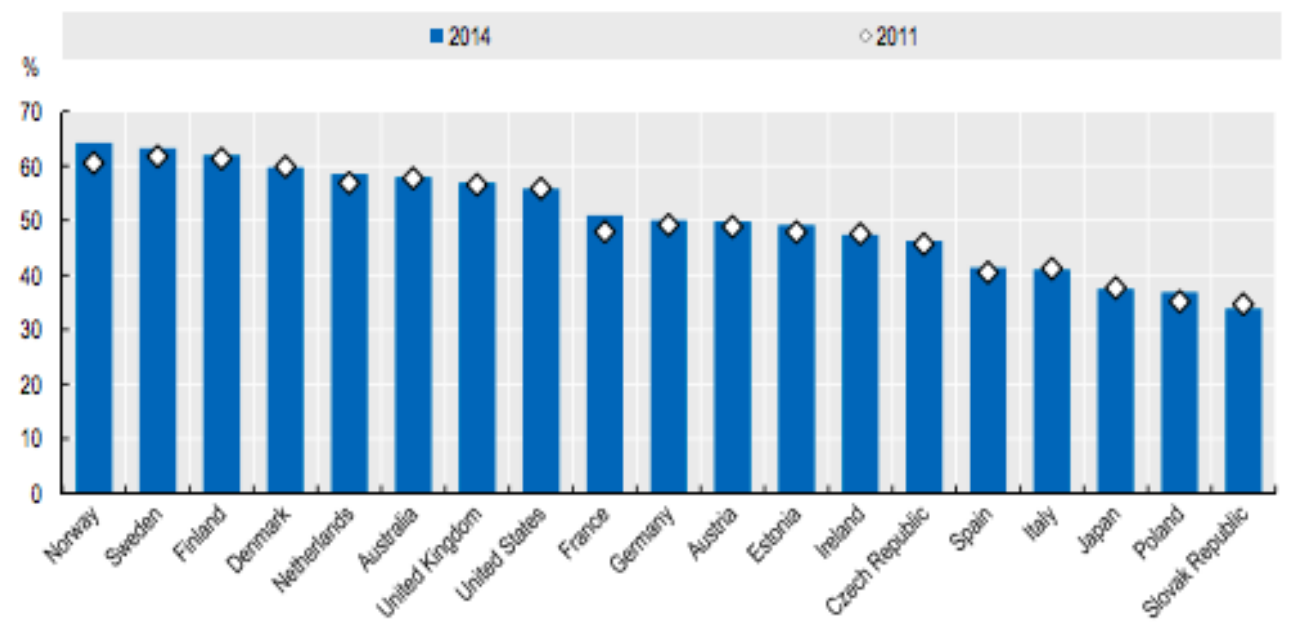

Fig. 2. Share of persons using ICT in everyday activity [4].

Figure 2 shows that the work intensity on a scale of the entire economy differs greatly in different countries. In 2014 the intensity of using ICT ranged from $64 \%$ of all occupations in Norway and $33 \%$ in SlovakRepublic. The employment share under conditions of ICT intensive use was stable in the period since 2011 till 2014 or in the majority of countries except Denmark, Ireland, Italy, Japan and Slovakia, where a minor reduction was noticed. The most significant growth has been noticed in Norway $(3.7 \%)$, next France $(2.9 \%)$ and Poland $(1.7 \%)$ are to follow.

The development of digital economics makes it possible to organize remote working places and compensate for shortage of manpower due to people from the other countries that has brought about the increase of international and multinational enterprises (MNE), who boast simpler ways of entering global markets. The information and communication technologies represent one of the most important triggers of international productiongrowth, since it simultaneously brings about intensification and development of cohabitation between ICT and international production[5]. Fig. 3 shows the architecture of digital economics formed by MNE. 


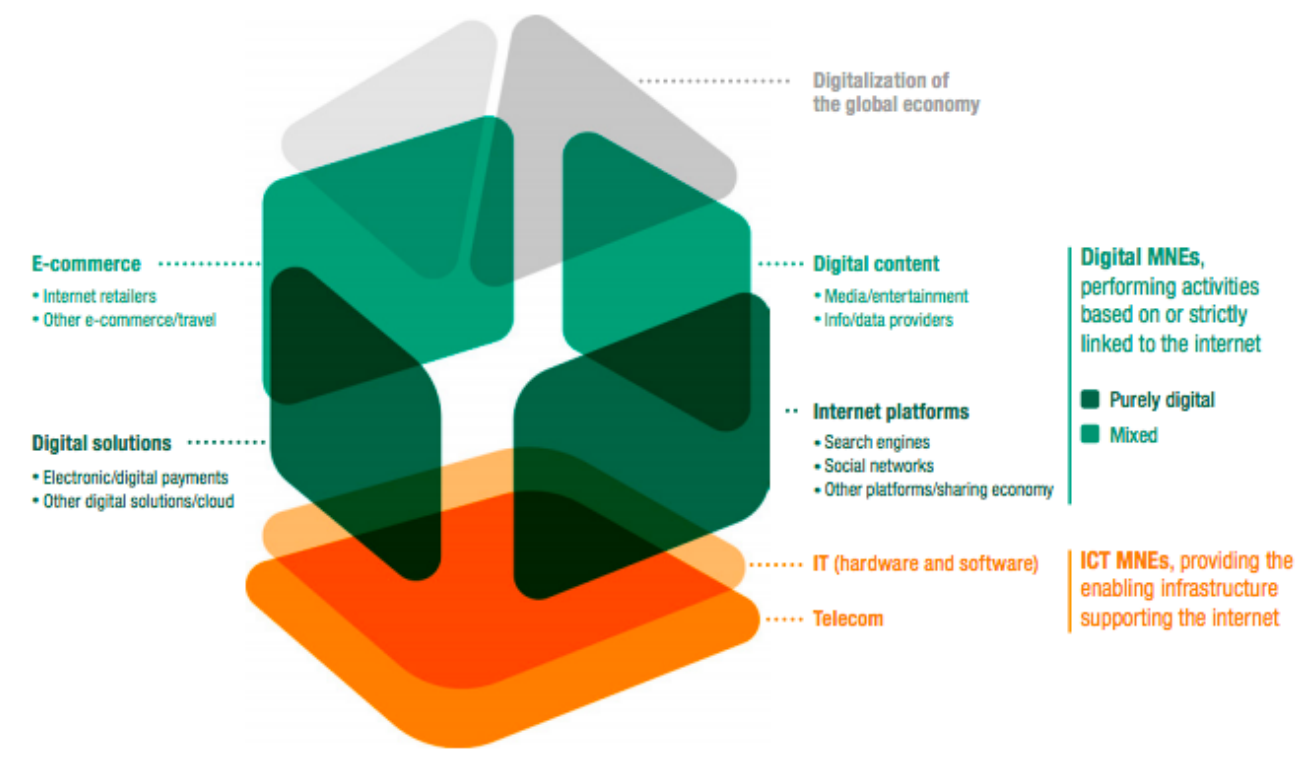

Fig. 3. Architecture of digital economics [5].

Analyzing this architecture one can come to a conclusion that the development of digital economics and MNE provides wider opportunities for restructuring processes and sales channels, reforming management mechanisms in global production networks, forming absolutely new models of international business and transition from traditional transnational corporations to virtual MNE, which international consequences of activity are absolutely different.

Under conditions of forming new industrial base the success of any organization in the market is provided in a great measure by the capacity of its competitive opportunities featuring rather dynamic than static character, since despite association of component elements of competitive opportunities to particular conditions and reasons of process of their formation and development, [6].

Presently, several scientific schools have been formed, the subject of which are the substance, composition of elements and structure of organization competitive opportunities. The article of B. Vernerfelt "Resource interpretation of company", which pointed out for the first time "profitability of analysis of a company rather from the point of view of its resources than products" has laid a basis of the "school of resources, capabilities and competencies". The articles of K. Prakhalad [7] and G. Khamel "Key competence of corporation", [8] R. Grant "Resource theory of competitive advantages. Practical findings for formulating strategy" [9] and D. Ties "Dynamic company's capabilities and strategic management" have made strong contribution into development of the resource-based theory[10].

The use of such notion as "production potential", which was used for the first time by A.I. Anchishkin in the 70s of XX century, was characteristic for the Soviet and Russian economic science for many years. The scholar considered it as a "set of resources, which take a shape of production factors in the process of production" [11].

The representatives of this school proceeded from the fact that the competitive opportunities get formed due to organization's individual characteristics, first of all, its capabilities, resources and competences (potentials). At the same time the competitive opportunities correspond to a combination of internal and external competitive opportunities of a company, which make it possible to run an effective competitive activity 
in the market due to manifestation of competitive opportunities based on using material and non-material resources $[12,13]$.

At present, an unalterable opinion has been formed in the economical science stating that competitiveness of organization depends to ever greater extent on the efficiency of using internal resources, than from an external environment[14].

The competitive opportunities feature two basic sources:

- exploitation of natural resource potential of the territory as well as production factors;

- innovation-based development.

This group of researchers divides competitive opportunities into two basic types: resource-factor and innovative-technological assuming a reasonable combination thereof.

Taking into account the definition of "digital economics", the authors offer in Fig. 2 a structure of competitive opportunities of organization under conditions of forming digital economics, which correspond to a system of interrelation of economical, social, financial, technical, technological and innovative aspects.

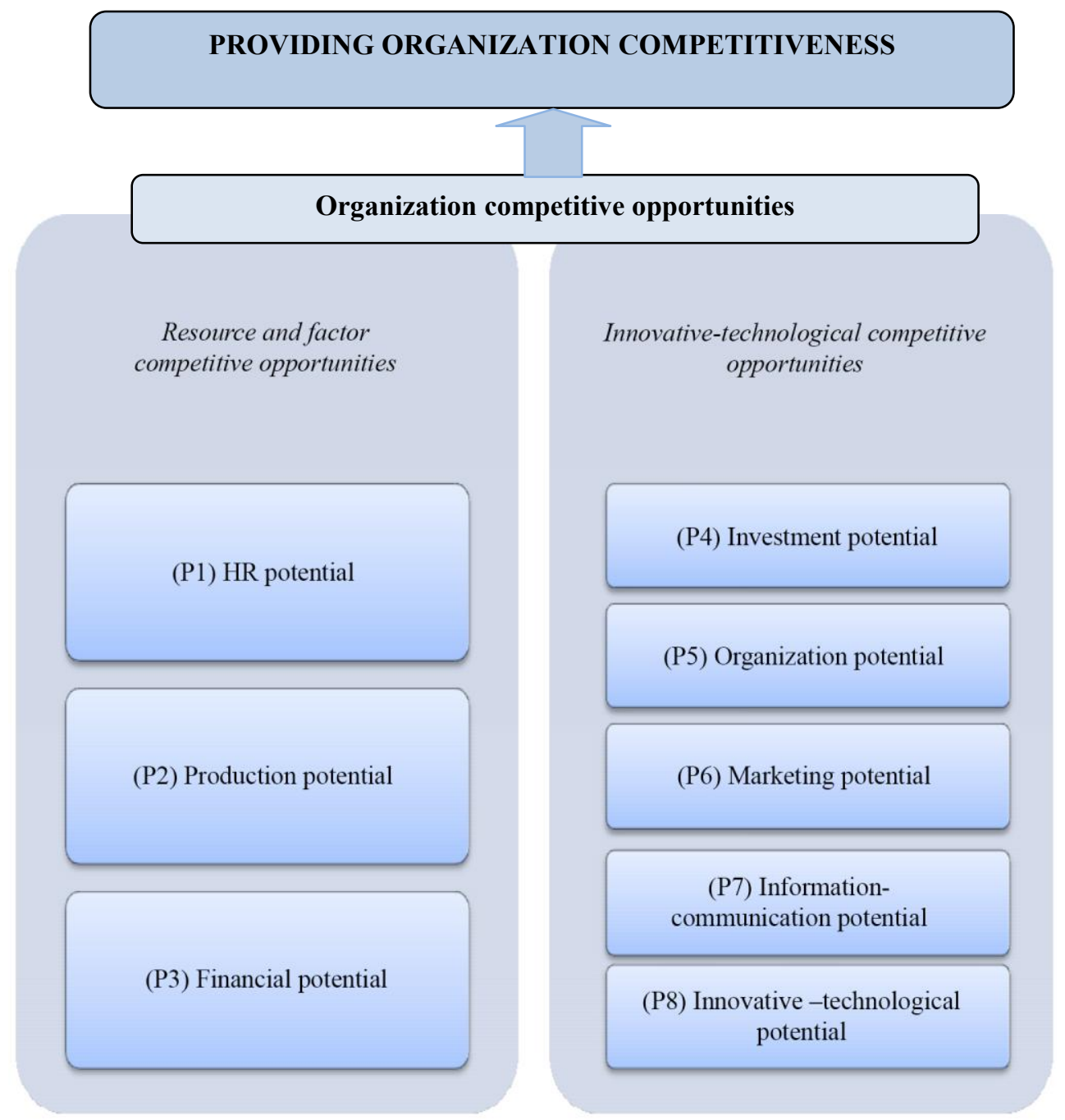

Fig. 4. Structure of competitive opportunities of organization under conditions of forming digital economics. 
Resource-factor competitive opportunities are different sources of formation and elements of the production and economic system of the organization.

The HR potential (P1) is a combination of competences and characteristics of organization employees as the main resource, which is closely connected with an effective execution of assigned tasks and attaining strategic goals of organization development. It should be noted that the main difficulty during incorporation of elements of digital economics and forming digital ecosystems will be not the selection of new promising technologies, but a high demand for new specialists (carriers of digital culture, which can emerge in digital community only) in the course of developing a system of knowledge management in this environment.

Production potential (P2) stands for the available and potential production capabilities, availability of very production factors, its provision with determinative types of resources, which depending on the branch of economy consist of the fixed assets, current assets and other resources, which are used or will be used directly in the production process.

Financial potential(P3) is characterized by availability and accessibility of sources of financing organization activity [15]. The following can be attributed to the elements of financial potential: sales volume; net profit; profitability of sales; capitalization; financial stability index, etc.

Innovative and technological co-advantage advantages allow not only to use new forms of marketing, production or after-sale services, but also to increase the period of retention of competitive advantages.

Investment potential(P4) is a maximum possible volume of investments, both internal and external, which are necessary and sufficient for providing financial-economic activity of organization in case of an effective use ofproduction capacities, human and other resources, streamlined investment activity and attractiveness of organization under particular conditions of investment climate and business cycle phase. The investment potentialof organization corresponds not only to organization's capability to invite and reasonably use internal and external investments, but an important function of scaled reproduction of enterprise's production capacity [16].

Organization potential (P5) is a system of organization and economical relations of the enterprise entities regarding efficient combination of production factors in space and time with the aim of establishing and distributing added value [17]. Digital platforms providing access and processing big volumes of information and its security shall become a basis of this system under conditions of forming a new production base.

Marketing potential (P6) is a combination of facilities and enterprise capabilities in implementation of marketing activity, i.e., a combination of indicators and factors characterizing its strength, sources, opportunities, means, capabilities and other abilities and other production resources, which can be used in economical activity [18].

Under conditions of digital economics the organizations gain additional channels of promoting goods and services to the market, methods and tools of interaction with target audience (Internet portals, social media, etc.), without which it is impossible to provide its competitiveness.

Information-communication potential (P7) denotes a level of used technologies, methods and conditions making it possible to efficiently use the informationcommunication reserves, including a level of providing information security, providing regulation and coordination of actions of all participants of organization business processes, set and attain common goals, system extension and, if necessary, scaling.

Innovative-technological potential (P8) is a combination of organization resources and capabilities providing incorporation of innovations both in production and in the business processes and making a basis for a model of organization economic potential development considering its influence on the growth of efficiency of organization activity. 
In spite of the fact that the competitive capabilities are the basic component of organization competitiveness and boasts the features of a complex dynamic socialeconomic system, it is possible to influence the advantageous competitive positions of organization in the market only under condition of an efficient interaction of all resources, potentials and taking into account factors of external and internal environment, where a new industrial base gets formed. The formation of such an environment, as practice of great Britain [19], Denmark [20], Singapore [21] and other developed countries shows, is possible only under condition of state-level incorporation of utilization of innovative and information-communicationtechnologies in all key branches of economy: industry, transport, financial sector, trade, housing and utilities infrastructure, education, public health service and state management, which help organizations get timely adapted to the changing conditions of social-economic relations and entrepreneurial activity.

\section{References}

1. D. Reinsel, J. Gantz, J. Rydning, Data Age 2025: The Evolution of Data to LifeCritical[online], Available at: https://www.seagate.com/files/www-content/ourstory/trends/files/Seagate-WP-DataAge2025-March-2017.pdf (2017)

2. B. Chakravorti, R. Shankar, Digital Planet 2017: How Competitiveness and Trust in Digital Economies Vary Across the World[online], Available at: https://sites.tufts.edu/digitalplanet/files/2017/05/Digital_Planet_2017_FINAL.pdf (2017)

3. Program "Digital Economics of the Russian Federation" approved by the Resolution of the Government No.1632-r (2017)

4. New skills for the digital economy measuring the demand and supply of its skills at work. Ministerial meeting on the digital economy [online], Available at: http://www.oecd-ilibrary.org/docserver/download/5jlwnkm2fc9xen.pdf?expires $=1516737638 \& \mathrm{id}=\mathrm{id} \&$ accname $=$ guest $\&$ checksum $=125 \mathrm{AF} 889 \mathrm{D} 7 \mathrm{~A} 773 \mathrm{~A}$ FB386F570FF717AF4 (2016)

5. UNCTAD,Investment and the Digital Economy World Investment Report [online], Available at: http://unctad.org/en/pages/PublicationWebflyer.aspx?publicationid=1782 (2017)

6. I.V. Savenkova, M.I. Kulsh, MolodoyUchenyi, 20 (2014)

7. B.A. Wernerfelt, Strategic ManagementJournal, 5 (2) (1984)

8. K.K. Pakhalad, G. Khamel, Bulletin of St. Petersburg State University (Management), 3 (2003)

9. R.M. Grant, Bulletin of St. Petersburg State University (Management), 3 (2003)

10. D.J. Ties, G. Pizano, E. Shuen, Bulletin of St. Petersburg State University (Management),3(2003)

11. A.I. Anchishkin, Forecasting Rates and Factors of Economic Development of Socialist Economics (Ekonomika, Moscow, 1973)

12. I.A. Arenkov, Ya.Yu. Salikhova, M.A. Gavrilova, Problemy Sovremennoi Ekonomiki, $4(2011)$

13. A.A. Suska, Molodoy Uchenyi, 12 (2012)

14. I.V. Savenkova, Competitive Advantages in a System of Market Relations (Konstanta, Belgorod, 2011)

15. M.V. Kudina, Theory of Company's Cos t(Infra-M, Moscow,2013)

16. A.V. Kozik, Investment Potential of Enterprises (Ways and Factors of its Strengthening and Effective Use) (Orel, 2000) 
17. V.N. Belkin, O.A. Antonova, V.D. Gorbunov, Organizational Capital of an Enterprise(Institute of economics, the Ural branch of Russian Academy of Sciences, Ekaterinburg, 2011)

18. D.V. Tolstykh, Marketing Potential as a Factor of Territory Social and Economic Development (Moscow, 2013)

19. UK Digital Strategy [online], Available at: https://www.gov.uk/government/publication s/uk-digital-strategy (2018)

20. About the Digitalization Strategy 2016-2020 [online], Available at: https://digst.dk/strategier/digitaliseringsstrategien/om-digitaliseringsstrategien-2016$\underline{2020 /(2018)}$

21. Official site of Data.gov.sg [online], Available at: https://data.gov.sg/about(2018) 